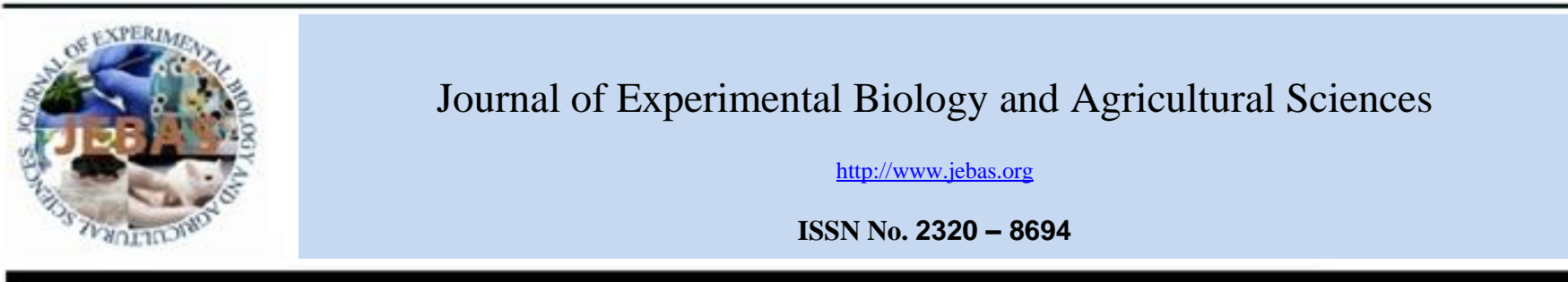

\title{
STABILITY OF THIOAMIDE TYPE OF PIPERINE UNDER ACIDIC AND BASIC CONDITIONS
}

\author{
Nurul Hikma, Risfah Yulianty, Muhammad Aswad*
}

Faculty of Pharmacy, Universitas Hasanuddin, Makassar, Indonesia 90245

Received - December 11, 2020; Revision - March 21, 2021; Accepted - May 09, 2021

Available Online - September 08, 2021

DOI: http://dx.doi.org/10.18006/2021.9(Spl-2-ICOPMES_2020).S259.S263

\section{KEYWORDS \\ Thiopiperine \\ Acidic and basic conditions \\ Degradation \\ Chromatography \\ Cancer}

\begin{abstract}
Thioamide type of piperine, "thiopiperine" is a derivate of piperine that having high potency against breast cancer cells. This research was intended to evaluate the stability of thiopiperine under highly acidic and basic conditions for $72 \mathrm{~h}$ at $60^{\circ} \mathrm{C}$. This study was conducted by the SHIMADZU ${ }^{\circledR}$ UFLC system integrated with a PDA detector, while the analysis was performed in an isocratic separation mode using column C-18 (COSMOSIL $^{\circledR}$ ), $150 \mathrm{~mm}$ x $4.6 \mathrm{~mm}$, column particle size: $5 \mu \mathrm{m}$. Chromatography condition was set using a mobile phase consisting of $50 \%$ aqueous acetonitrile with a flow rate of $1 \mathrm{~mL} / \mathrm{min}$, while the detection wavelength was $340 \mathrm{~nm}$. The result showed that thiopiperine undergoes extensive degradation under acidic and basic environments.
\end{abstract}

* Corresponding author

E-mail: aswadfar@unhas.ac.id (Muhammad Aswad)

Peer review under responsibility of Journal of Experimental Biology and Agricultural Sciences.

Production and Hosting by Horizon Publisher India [HPI] (http://www.horizonpublisherindia.in/).

All rights reserved.
All the articles published by Journal of Experimental Biology and Agricultural Sciences are licensed under a Creative Commons Attribution-NonCommercial 4.0 International License Based on a work at www.jebas.org.

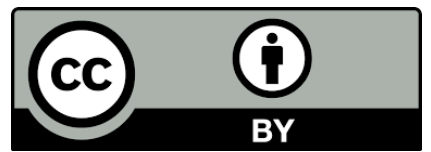




\section{Introduction}

Piperine, an alkaloid compound derived from pepper (Piper nigrum L.), has various pharmacological effects such as antiinflammatory, anticancer, antiviral, anti-allergic, anti-epileptic, anti-depressant, and anti-Alzheimer's (Shinwari et al., 2019; Stojanović-Radić et al., 2019). Further, it also magnifies the bioavailability of several drugs such as midazolam, diclofenac, resveratrol, isoniazid, domperidone, simvastatin, verapamil, and beta-lactam antibiotic (Tiwari et al., 2020). Structurally piperine has an amide skeleton that can be modified to optimize its pharmacological activities or minimize its adverse effects. Derivatization of piperine has been reported with various analogs and it has various pharmacological effects such as anti-fungal (Souza et al., 2021), PPAR $\gamma$ agonists (Wang et al., 2020), MAO-B inhibitors (Chavarria et al., 2020), anti-neuroinflammatory (Shahbazi et al., 2020), larvicidal (Tantawy et al., 2020), and antitumor (Rifai et al., 2016; Ferreira et al., 2020).

Due to the high medicinal potential of piperine, recently, a derivative compound thioamide-type of piperine (thiopiperine) had been synthesized by modifying the structure of piperine from black pepper. The compound was modified by converting the carbonyl group to a sulfur analog (thiocarbonyl) using lawesson's reagent (Figure 1). Aswad (2019) suggested that this compound shows activity against $4 \mathrm{~T} 1$ breast cancer cells, therefore, this compound can be potentially used in the development of cancer treatment drugs.
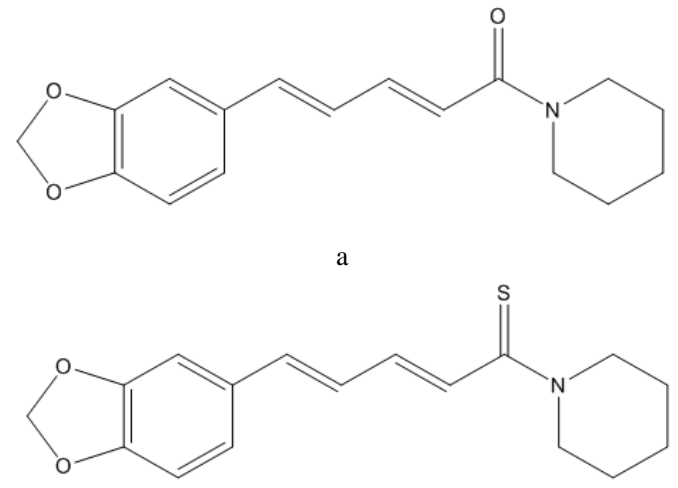

b

Figure 1 Structure of piperin (a) and Thioamide-type of piperine (b)

In the manufacturing of any drug, data about its stability as candidate active pharmaceutical ingredients must be considered, because it will affect various qualities such as safety and efficacy before it becomes a drug product. According to ICH guidelines, the quality of drug substances and drug products changes with storage time and is influenced by several stress conditions such as acidic, basic, peroxide, temperature, and lights. Furthermore, the determination of stability has only focused on drug products, while data on the stability of the active pharmaceutical ingredients (API) is still less (Blessy et al., 2014). Therefore, this research aimed to determine the stability of thiopiperine as a candidate of API under highly acidic and basic environments.

\section{Materials and Methods}

\subsection{Materials}

The materials used in this study are black pepper, piperine (Wako, Japan), acetonitrile (Merck), water pro-HPLC (Merck), Lawesson's Reagent (Wako, Japan), Tetrahydrofuran (THF) (Merck), Dichloromethane (DCM) (Merck), NaOH (SigmaAldrich), $\mathrm{HCl}$ (Merck). All of the chemicals were used without further purification.

\subsection{Synthesis of thiopiperine}

Thiopiperine was prepared by the semi-synthesis method from black pepper (Piper nigrum) as suggested by Aswad (2019). Ground black pepper ( $10 \mathrm{~g}$ ) was refluxed in DCM for 30 minutes followed by evaporation of the solvent in vacuo. Cold ether was applied to obtain crude piperine as pale brown solid $(126 \mathrm{mg})$. Subsequently, crude piperine, Lawesson's reagent (162 mg), and 2 $\mathrm{mL}$ THF were added into the round bottom flask. The mixture was stirred at room temperature for $24 \mathrm{~h}$. After evaporation of the solvent, the product was purified by flash column chromatography with solvent DCM: EtOAc (2:1) to generate thiopiperine (29 mg) as a bright orange solid.

\subsection{Preparation of stock solution}

$1 \mathrm{mg}$ of thiopiperine was dissolved in $10 \mathrm{~mL}$ of acetonitrile to make a solution of thiopiperine $(100 \mu \mathrm{g} / \mathrm{mL})$. In addition, $2.5 \mathrm{~mL}$ of stock solution $(100 \mu \mathrm{g} / \mathrm{mL})$ was placed into a $5 \mathrm{~mL}$ volumetric flask, and then acetonitrile was added up to a $5 \mathrm{~mL}$ line $(50 \mu \mathrm{g} / \mathrm{mL})$.

\subsection{Instrumentation and chromatographic conditions}

HPLC analysis was performed on UFLC Shimadzu ${ }^{\circledR}$ with a PDA detector $(\lambda=340 \mathrm{~nm})$. The separation was conducted on a C-18 column (Cosmosil ${ }^{\circledR}, 5 \mu \mathrm{m}, 4.6 \times 150 \mathrm{~mm}$ ) with aqueous acetonitrile (50\% acetonitrile) as a mobile phase. The flow rate was set 1 $\mathrm{mL} /$ minute, injection volume was $20 \mu \mathrm{L}$, while analytical run time was $20 \mathrm{~min}$.

\subsection{Stability stress testing}

\subsubsection{Acidic degradation}

$100 \mu \mathrm{L}$ of stock solution was placed into a vial, then $900 \mu \mathrm{L}$ of 0.1 $\mathrm{N} \mathrm{HCl}$ was added $(5 \mu \mathrm{g} / \mathrm{mL})$. The solution was mixed thoroughly, after that it was stored at $60^{\circ} \mathrm{C}$ for $72 \mathrm{~h}$. Sampling was conducted at $24 \mathrm{~h}$ and $72 \mathrm{~h}$ by transfer $100 \mu \mathrm{L}$ of solution into vial then the volume was adjusted with $900 \mu \mathrm{L}$ of acetonitrile. The prepared mixture was analyzed by HPLC. 


\subsubsection{Alkaline degradation}

Alkaline degradation was prepared as similar to acidic degradation's procedure, in this $0.1 \mathrm{~N} \mathrm{NaOH}$ was utilized instead of $0.1 \mathrm{~N} \mathrm{HCl}$ as a degradation agent.

\section{Results and Discussion}

Forced degradation study is the process of determining stability that involves degradation of drug substances or drug products at conditions more severe than accelerated conditions, in this case, forced degradation studies help in generating degradants in a shorter period, mostly 2 weeks (Teasdale et al., 2018). To quantify the number of degradants within the forced degradation study, an integrated HPLC system was applied as a stability-indicating $\mathrm{uV}$

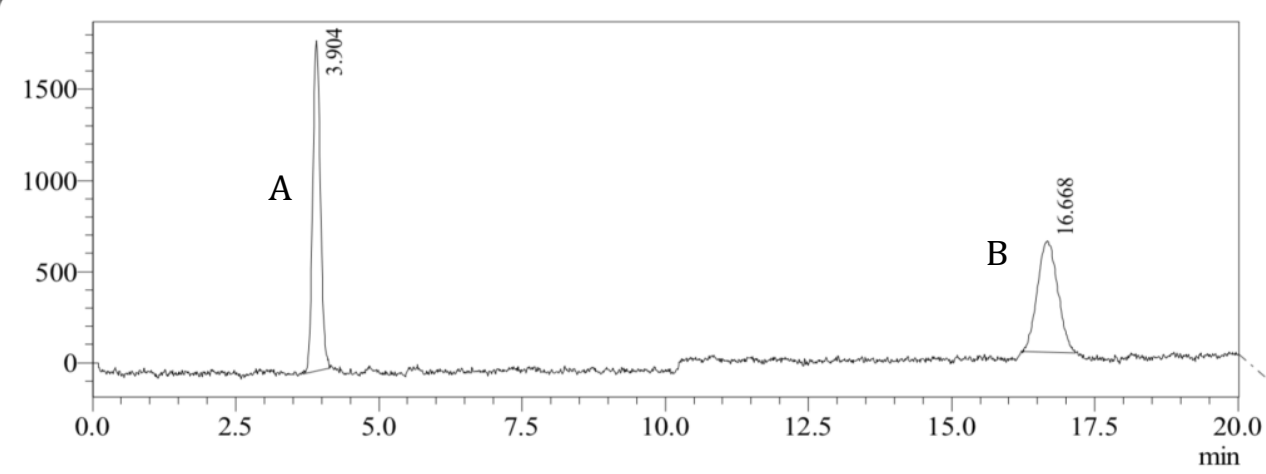

Figure 2 Chromatogram of piperine (A) and thiopiperine (B) on UFLC Shimadzu®, C-18 column (Cosmosil@, 5- $\mu \mathrm{m}, 4.6 \mathrm{~mm} \times 150 \mathrm{~mm})$ with a mobile phase acetonitrile:water $(50: 50 \mathrm{v} / \mathrm{v})$ at flow rate $1 \mathrm{~mL} / \mathrm{min}$.
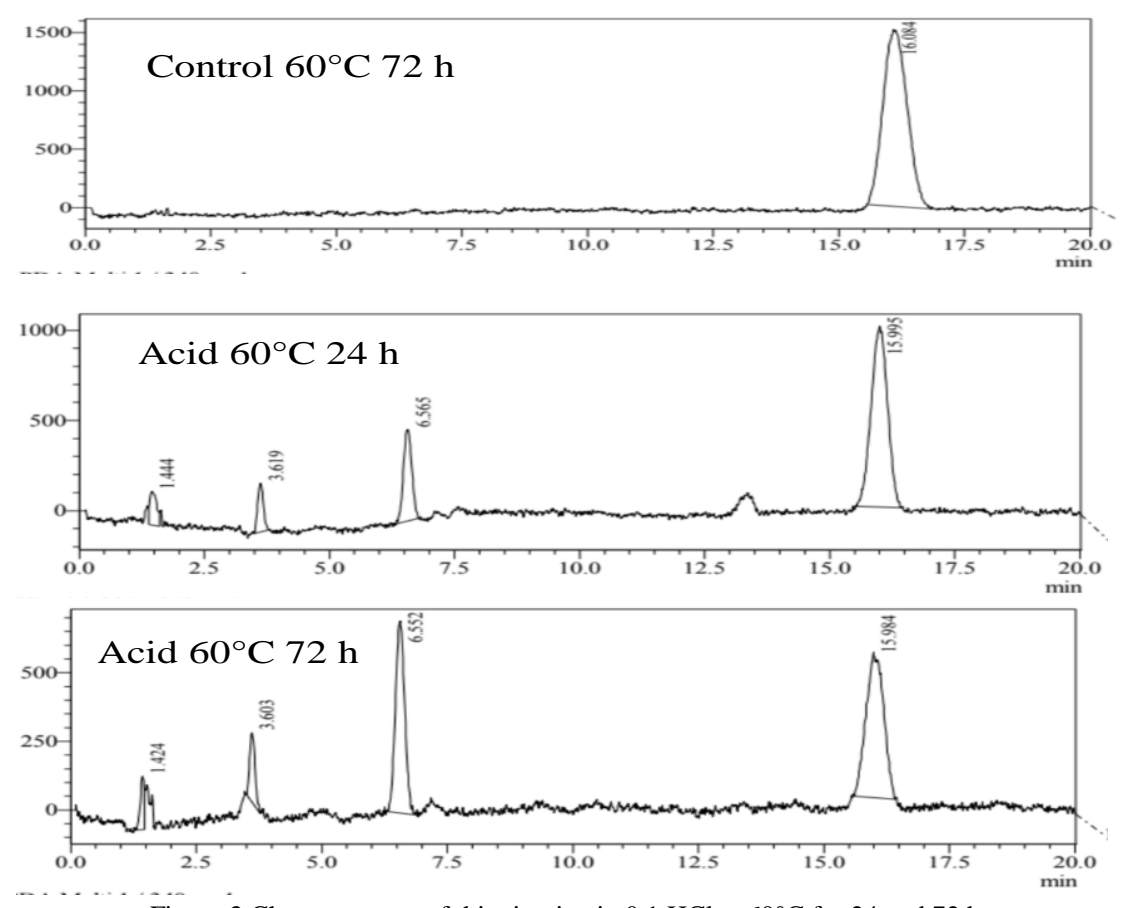

Figure 3 Chromatogram of thiopiperine in $0.1 \mathrm{HCl}$ at $60^{\circ} \mathrm{C}$ for 24 and $72 \mathrm{~h}$

Journal of Experimental Biology and Agricultural Sciences http://www.jebas.org 
The data indicated that thiopiperine is more lipophilic than piperine, consider the greater energy of the thiocarbonyl's $\pi$-orbital than carbonyl resulting in the electronegativity of thiocarbonyl is less than carbonyl. On the other hand, the polarity of carbonyl is slightly superior to thiocarbonyl (Abboud et al., 1993).

Stress testing of thiopiperine was accomplished in the existence of strong acid $(0.1 \mathrm{~N} \mathrm{HCl})$, and strong base $(0.1 \mathrm{~N} \mathrm{NaOH})$ at $60^{\circ} \mathrm{C}$ for 72h. For acid treatment, thiopiperine solution in $0.1 \mathrm{~N} \mathrm{HCl}$ environment exhibited degradation process occurred within $24 \mathrm{~h}$ after contact with strong acid.

Figure 3 showed that degradants were generated due to the acid environment indicated by new peaks appeared at $1.4 \mathrm{~min}, 3.6 \mathrm{~min}$, and 6.5 min within $24 \mathrm{~h}$ of treatment. In addition, the peak area increased with time. Subsequently, the main peak around $16.0 \mathrm{~min}$ was gradually degraded by the time. About $55 \%$ of thiopiperine was decayed within $24 \mathrm{~h}$ then extensive degradation was occurred up to $75 \%$ within $72 \mathrm{~h}$.

Similar to acidic hydrolysis, thiopiperine exhibited a strong degradation under an alkaline environment also (Figure 4). New peaks appeared at $2.3 \mathrm{~min}, 2.6 \mathrm{~min}, 3.6 \mathrm{~min}$, and $6.5 \mathrm{~min}$ when the thiopiperine was exposed with aqueous $\mathrm{NaOH}(0.1 \mathrm{~N})$ for $24 \mathrm{~h}$ at $60^{\circ} \mathrm{C}$. The main peak ( $16.0 \mathrm{~min}$ ) was steadily diminished by about $49 \%$ within $24 \mathrm{~h}$ and decreased $70 \%$ within $72 \mathrm{~h}$. In both acidic and basic conditions, thiopiperine underwent a degradation process with time. However, the compound might decay rapidly under acidic conditions than the basic environment.
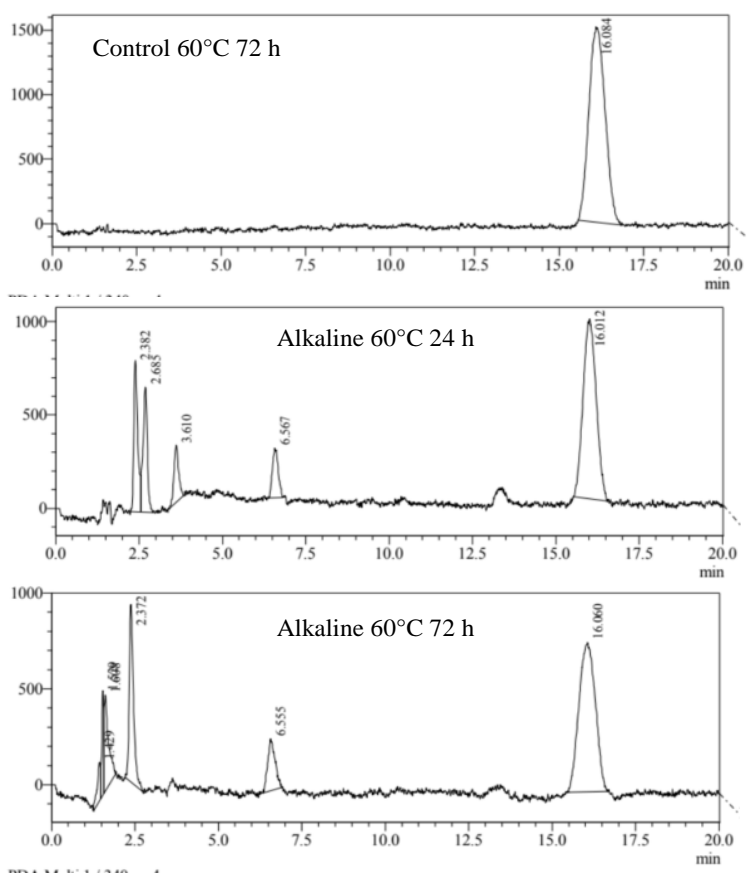

Figure 4 Chromatogram of thiopiperine in $0.1 \mathrm{NaOH}$ at $60^{\circ} \mathrm{C}$ for $72 \mathrm{~h}$

\section{Conclusion}

The stability of thiopiperine investigated through the stabilityindicated HPLC method exhibited that the compound was unstable after stress testing for 3 days at $60^{\circ} \mathrm{C}$ in acidic and basic conditions. The compound was likely to degrade faster under acidic than the basic environment.

\section{Acknowledgment}

The authors are thankful to DRPM DIKTI Republic of Indonesia for their financial support via the PenelitianTesis Magister2020 research grant (1517/UN4.22/PT.01.03/2020)

\section{Conflict of Interest}

The authors declare that there is no conflict of interest

\section{References}

Abboud JLM, Mo O, de Paz JLG, Yhiiez M, Esseffar M, Bouab W, El-Mouhtadi M, Mokhlisse R, Ballesteros E, Herreros M, Homan H, Lopez-Mardomingo C, Notario R (1993) Carbonyl Compounds: A Comparison of Intrinsic Reactivities. Journal of the American Chemical Society 347: 12468-12476.

Abdelwahab NS, Abdelrahman MM, Boshra JM, Taha AA (2019) Different stability-indicating chromatographic methods for specific determination of paracetamol, dantrolene sodium, their toxic impurities and degradation products. Biomedical Chromatography 33(9):e4598. doi: 10.1002/bmc.4598.

Aswad M (2019) Semi synthetic of piperine's derivatives derived from Piper nigrumL. as the candidate of anticancer. Research Report.

Blessy M, Patel RD, Prajapati PN, Agrawal YK (2014) Development of forced degradation and stability indicating studies of drugs - A review. Journal of Pharmaceutical Analysis 4: 159165. https://doi.org/10.1016/j.jpha.2013.09.003.

Chavarria D, Fernandes C, Silva V, Silva C, Gil-Martins E, Soares P, Silva T, Silva R, Remião F, Oliveira PJ, Borges F (2020) Design of novel monoamine oxidase-B inhibitors based on piperine scaffold: Structure-activity-toxicity, drug-likeness and efflux transport studies. European Journal of Medicinal Chemistry 185: 111770. https://doi.org/10.1016/j.ejmech.2019.111770.

Ferreira RC, Batista TM, Duarte SS, Silva DKF, Lisboa TMH, Cavalcanti RFP, Leite FC, et al. (2020) A novel piperine analogue exerts in vivo antitumor effect by inducing oxidative, antiangiogenic and immunomodulatory actions. Biomedicine \& Pharmacotherapy https://doi.org/10.1016/j.biopha.2020.110247.

Journal of Experimental Biology and Agricultural Sciences http://www.jebas.org 
Rifai Y, Tani HB, Nur M, Aswad M, Lallo S, Wahyudin E (2016) Synthesis, Molecular Mechanism and Pharmacokinetic Studies of New Epoxy Lignan-Based Derivatives. Archiv der Pharmazie (Weinheim) 349. https://doi.org/10.1002/ardp.201600069.

Shahbazi S, Zakerali T, Frycz B, Kaur J (2020) Impact of novel Naryl substituted piperamide on NF-kappa B translocation as a potent anti-neuroinflammatory agent. Biomedicine \& Pharmacotherapy 127: 110199 . DOI: https://doi.org/10.1016/ j.biopha.2020.110199.

Shinwari Z, Tumer T, Zakaria Z, Ibrahim S, Rajkovic J, Setzer W, Turkdonmez E, et al. (2019) Piper species: A comprehensive review on their phytochemistry, biological activities and applications. Molecules 24: 1364. https://doi.org/10.3390/ molecules24071364.

Souza JS, Martins EPS, Souza HDS, de Oliveira RF, Alves FS, Lima EO, Cordeiro LV, et al. (2021). Synthesis, spectroscopic characterization, DFT calculations and preliminary antifungal activity of new piperine derivatives. Journal of the Brazilian Chemical Society 32: 490-502. DOI: https://doi.org/10.21577/ 0103-5053.20200203.
Stojanović-Radić Z, Pejčić M, Dimitrijević M, Aleksić A, Anil Kumar NV, Salehi B, Cho WC, Sharifi-Rad J (2019) Piperine-A Major Principle of Black Pepper: A review of its bioactivity and studies. Applied Sciences 9 (4270). https://doi.org/10.3390/app9204270.

Tantawy AH, Farag SM, Hegazy L, Jiang H, Wang MQ (2020) The larvicidal activity of natural inspired piperine-based dienehydrazides against Culex pipiens. Bioorganic Chemistry 94: 103464. https://doi.org/10.1016/j.bioorg.2019.103464.

Teasdale A, Elder D, Nims RW (2018) ICH Quality Guidelines: An Implementation Guide, John Wiley \& Sons, Inc. https://doi.org/10.1002/9781118971147.ch0.

Tiwari A, Mahadik KR, Gabhe SY (2020) Piperine: A comprehensive review of methods of isolation, purification, and biological properties. Medicine in Drug Discovery 7: 100027. https://doi.org/10.1016/j.medidd.2020.100027.

Wang Y, Yao Y, Liu J, Wu L, Liu T, Cui J, Lee DYW (2020) Synthesis and biological activity of piperine derivatives as potential PPAR $\gamma$ agonists. Drug Design, Development and Therapy 14: 2069-2078. https://doi.org/10.2147/DDDT.S238245. 